\title{
High Arabian Sea productivity conditions during MIS 13 - odd monsoon event or intensified overturning circulation at the end of the Mid-Pleistocene transition?
}

\author{
M. Ziegler ${ }^{1}$, L. J. Lourens ${ }^{1}$, E. Tuenter ${ }^{2}$, and G.-J. Reichart ${ }^{1,3}$ \\ ${ }^{1}$ Department of Earth Sciences, Utrecht University, Utrecht, The Netherlands \\ ${ }^{2}$ Institute for Marine and Atmospheric research Utrecht (IMAU), Utrecht University, Utrecht, The Netherlands \\ ${ }^{3}$ Alfred Wegener Institute for Polar and Marine Research, Bremerhaven, Germany
}

Received: 14 July 2009 - Published in Clim. Past Discuss.: 27 July 2009

Revised: 30 November 2009 - Accepted: 3 December 2009 - Published: 29 January 2010

\begin{abstract}
Marine isotope stage (MIS) 13 ( 500000 years ago) has been recognized as atypical in many paleoclimate records and, in particular, it has been connected to an exceptionally strong summer monsoon throughout the Northern Hemisphere. Here, we present a multi-proxy study of a sediment core taken from the Murray Ridge at an intermediate water depth in the northern Arabian Sea that covers the last 750000 years. Our results indicate that primary productivity conditions were anomalously high during MIS 13 in the Arabian Sea and led to extreme carbonate dissolution and glauconitization in the deep-sea sediments. These observations could be explained by increased wind driven upwelling of nutrient-rich deep waters and, hence, by the occurrence of an exceptionally strong summer monsoon event during MIS 13, as it was suggested in earlier studies. However, ice core records from Antarctica demonstrate that atmospheric methane concentrations, which are linked to the extent of tropical wetlands, were relatively low during this period. This constitutes a strong argument against an extremely enhanced global monsoon circulation during MIS 13 which, moreover, is in contrast with results of transient climate modelling experiments. As an alternative solution for the aberrant conditions in the Arabian Sea record, we propose that the high primary productivity was probably related to the onset of an intensive meridional overturning circulation in the Atlantic Ocean at the end of the Mid-Pleistocene transition. This may have led to an increased supply of nutrient-rich deep waters into the Indian Ocean euphotic zone, thereby triggering the observed productivity maximum.
\end{abstract}

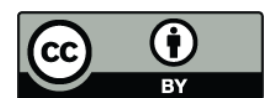

Correspondence to: M. Ziegler

(ziegler@geo.uu.nl)

\section{Introduction}

The Mid-Pleistocene transition (MPT) characterises a fundamental change in the climate state which allowed ice sheets to expand and evolve from a dominant 41-kyr (obliquity) to a quasi $\sim 100$-kyr rhythm (Clark et al., 2006; Lisiecki and Raymo, 2005; Raymo and Nisancioglu, 2003; Raymo et al., 2006; Shackleton and Opdyke, 1976). The end of the MPT between ca. 600 and $500 \mathrm{ka}$ is described by a series of events (Schmieder et al., 2000). First, the transition between MIS 14 and 13 (i.e. termination $\mathrm{T}_{\mathrm{VI}}$ ) is the least pronounced termination of the past $640 \mathrm{ka}$. Ice volume has increased insignificantly during MIS 14, compared to the other late Pleistocene glacial periods. A record from Lake Baikal indicates, for instance, that mountain glaciations were reduced in central Eurasia from 580 to $380 \mathrm{kyrs}$ ago (Prokopenko et al., 2002). In particular, the record documents a continuous forestation, suggesting that mild winter conditions prevailed with relatively little snow cover.

MIS 13 is, on the other hand, exceptional. It marks an extreme $\delta^{13} \mathrm{C}_{\max }$ associated with a major reorganization in the carbon reservoir of the global ocean (Wang et al., 2003). Several peculiarities occured in the ocean during this time, such as thick laminated layers of the giant diatom Ethmodiscus rex in the Atlantic Ocean (Romero and Schmieder, 2006). Also, the climate changed dramatically during this period with high terrigenous influx at Ceara Rise (Harris et al., 1997), indicating heavy precipitation in the Amazon Basin, or the exceptional thick soil horizon S5 found at the Chinese loess plateau (CLP) (Guo et al., 2009; Sun et al., 2006b). Moreover, extreme African and Indian monsoon intensity, inferred from the occurrence of the anomalous sapropel $\mathrm{Sa}$ in the Mediterranean and a peak in planktic oxygen isotope records from the equatorial Indian Ocean (Bassinot et al., 1994a; Rossignol-Strick et al., 1998), is commonly linked to this event (Guo et al., 2009; Yin and Guo, 2008).

Published by Copernicus Publications on behalf of the European Geosciences Union. 
(a)

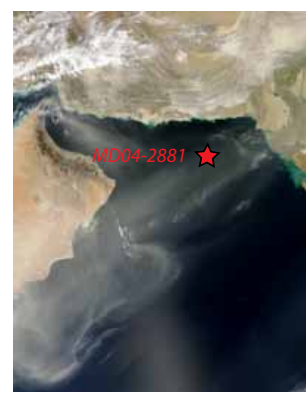

(b)

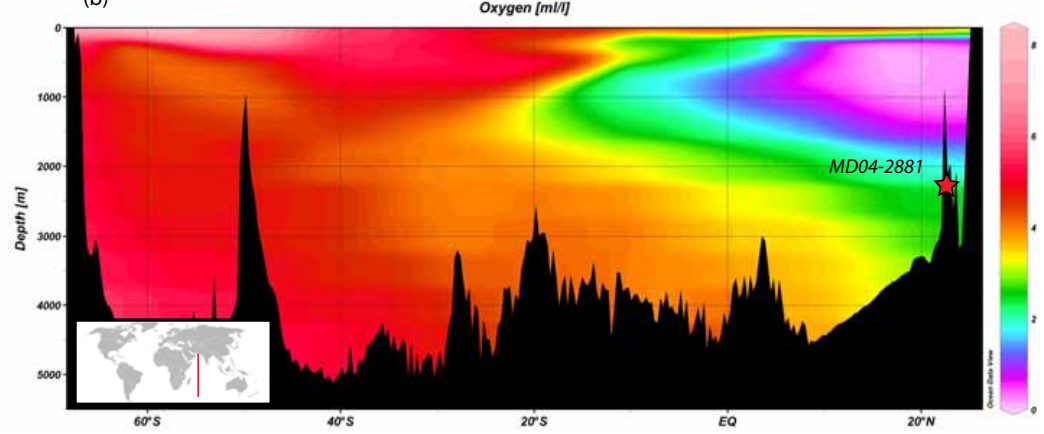

Fig. 1. (a) NASA's Aqua satellite picture, using the Moderate Resolution Imaging Spectroradiometer (MODIS) on 3 March 2009 (http: //earthobservatory.nasa.gov/NaturalHazards). The star indicates position of IMAGES Core MD04-2881 was recovered on 14 October 2004, from a water depth of $2387 \mathrm{~m}$ at the Murray Ridge $\left(22^{\circ} 12^{\prime} .5 \mathrm{~N}-63^{\circ} 05^{\prime} .5 \mathrm{E}\right)$ in the northeastern Arabian Sea (b) Oxygen profile through the northern Arabian Sea.

Furthermore, the transition between MIS 14 and 13 coincides with the onset of the Mid-Brunhes dissolution interval (MBDI), which lasts until 280 ka (Barker et al., 2006; Bassinot et al., 1994b; Droxler et al., 1988). This period of extensive dissolution in the deep sea is probably not related to enhanced greenhouse gas forcing, since Antarctic ice core data and foraminiferal boron isotopes generally indicate low atmospheric $p \mathrm{CO}_{2}$ levels, even within interglacial periods during this time (Hönisch et al., 2009; Petit, 1999). An alternative explanation for the MBDI invokes an increase in lowlatitude shelf carbonate production (Droxler et al., 1997). To add to that, it has been suggested that pelagic carbonate production increased globally due to the proliferation of the coccolithophore Gephyrocapsa (Bollmann et al., 1998), thereby, causing widespread dissolution in the deep sea (Barker et al., 2006). The most severe dissolution occured during MIS 11, which followed on from the so-called Mid-Brunhes event at ca. $430 \mathrm{ka}$ (i.e. termination $\mathrm{T}_{\mathrm{V}}$ ), representing the largestamplitude change in $\delta^{18} \mathrm{O}$ of the global ocean over the past 6 million years (Wang et al., 2003).

In 2004, a long sediment core was recovered at the Murray Ridge, a submarine high in the northeastern Arabian Sea, from a water depth of $2387 \mathrm{~m}$, well below the present-day extension of the oxygen minimum zone (OMZ). The main aim of the investigation of this core was to investigate the paleoceanographic changes in the Arabian Sea during the MPT, since numerous studies only document these in great detail from the past 400000 years (Almogi-Labin et al., 2000; Altabet et al., 2002; Anderson et al., 2002; Budziak et al., 2000; Clemens et al., 1991; Clemens and Prell, 1990, 2003; Emeis et al., 1995; Gupta et al., 2003; Ishikawa and Motoyoshi, 2007; Ivanova et al., 2003; Jaeschke et al., 2009; Leuschner and Sirocko, 2000, 2003; Lückge et al., 2001; Naidu and Malmgren, 1996; Naidu, 2006; Pattan et al., 2003; Prabhu and Shankar, 2005; Prell et al., 1980; Prell and Campo, 1986; Prell and Kutzbach, 1992; Reichart et al., 1997, 1998, 2002, 2004; Rostek et al., 1993, 1997; Saher et al., 2007; Sarkar et al., 1990; Schmiedl and Leuschner, 2005; Schulte et al., 1999; Schulz et al., 1998; Sirocko et al., 1993, 1996; Wang et al., 2005a). Using a multi-proxy approach, we will report on the complex interplay of summer monsoon upwelling-related productivity changes, OMZ intensity, glacial-interglacial variability in intermediate water contributions, supralysoclinal carbonate dissolution and winter monsoon-related deep-mixing events. Special emphasis will be on the cause of the exceptional high productivity conditions in the Arabian Sea during MIS 13.

\section{Material and methods}

\subsection{Sediment core MD04-2881}

The sedimentary sequence of the Murray Ridge provides an excellent archive of past primary productivity and Indian summer monsoon intensity (Pourmand et al., 2004; Reichart et al., 1997, 1998, 2004; Schulz et al., 1998). IMAGES Core MD04-2881 was recovered on 14 October 2004, from a water depth of $2387 \mathrm{~m}$ at the Murray Ridge $\left(22^{\circ} 12^{\prime} .5 \mathrm{~N}-\right.$ $63^{\circ} 05^{\prime} .5 \mathrm{E}$ ) (Fig. 1). The sediment consists of homogeneous, dark brownish to olive greenish to light greenish/yellowish grey hemipelagic mud. The upper $34 \mathrm{~m}$ of the core have been sub-sampled in $10 \mathrm{~cm}$ resolution. XRF and magnetic susceptibility scans have been performed in $1 \mathrm{~cm}$ resolution.

\subsection{Analytical methods}

An Avaatech XRF core scanner at the Royal Netherlands Institute of Sea Research (NIOZ, Texel, Netherlands) has been used to measure the bulk elemental composition of the sediment core in high-resolution. The split core surface was cleaned and covered with a $4 \mu \mathrm{m}$ thin SPEXCertiPrep Ultralene foil to avoid contamination and prevent desiccation. Each section was scanned four times at 0.1 milliamps (mA)/5 kilovolts ( $\mathrm{kV}$ ) (no filter), $0.15 \mathrm{~mA}$ and 
$10 \mathrm{kV}$ (no filter), $0.5 \mathrm{~mA}$ and $30 \mathrm{kV}$ (Pd-thick filter) and $1 \mathrm{~mA} / 50 \mathrm{kV}$ (Cu-filter). A $1 \mathrm{~cm}^{2}$ area of the core surface was irradiated with X-rays using $30 \mathrm{~s}$ count time ( $120 \mathrm{~s}$ for the $50 \mathrm{kV}$ setup). For further technical details on the XRF scanning technique, see (Richter et al., 2006).

Reliability of XRF scanning counts has been tested by comparing it to a lower-resolution sample set $(10 \mathrm{~cm})$ for XRF measurements on discrete samples. 3-5 g of freezedried sediment was thoroughly ground. Residual moisture, organic matter and carbonates were removed using a Leco TGA (Thermo-Gravimetric Analysis), $600 \mathrm{mg}$ of the residue was mixed with $6 \mathrm{~g}$ flux (consisting of $66 \%$ lithium tetraborate, $\mathrm{Li}_{2} \mathrm{~B}_{4} \mathrm{O}_{7}$ and $34 \%$ lithium metaborate, $\mathrm{LiBO} 2$ ) and $0.500 \mathrm{ml}$ of a $30 \%$ lithium iodide solution and fused to glass beads. Glass beads were measured using an ARL9400 X-ray fluorescence spectrometer. Analytical precision, as checked by parallel analysis of international reference material and in-house standards, is better than $2 \%$ for $\mathrm{Al}$, Ti better than $3 \%$ for Ba.

In general, XRF scanning is less suited for light elements (Richter et al., 2006; Tjallingii et al., 2007). When comparing the elemental scanning counts for $\mathrm{Al}$ with the absolute measurements on discrete samples, we find a low correlation $\left(r^{2}=0.38\right)$. This low correlation coefficient implies that normalization to Aluminum (Al), which is commonly done for elemental data, will lead to large uncertainties for the XRF scanning dataset. We, therefore, rely only on the raw counts for Barium (Ba), Calcium (Ca), Strontium (Sr), the sum of the terrestrial elements and Bromine (Br). A comparison between depth profile of $\mathrm{Ba}$ scanning-counts with the $\mathrm{Ba} / \mathrm{Al}$ profile derived from conventional XRF measurements on discrete samples shows a perfect match between the two (Fig. 3d). This perfect match is why we conclude that closed-sum issues did not influence our record, in this particular case.

Magnetic susceptibility of discrete samples was measured on a Kappabridge KLY-2. Susceptibility was divided by the sample's dry weight, giving the mass magnetic susceptibility $\left[\mathrm{m}^{3} / \mathrm{kg}\right]$.

Stable isotope ratios were measured on the benthic foraminifera Uvigerina peregrina (single specimen, size frac-

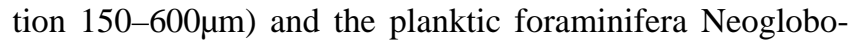
quadrina dutertrei ( $\sim 20$ specimen, $300-350 \mu \mathrm{m})$ and Globigerinoides ruber $(\sim 50$ specimen, $212-300 \mu \mathrm{m})$. A single specimen of the benthic foraminifera and aliquots of the homogenized G. ruber samples were loaded into individual reaction vessels and each sample reacted with three drops of $\mathrm{H}_{3} \mathrm{PO}_{4}$ (specific gravity =1.92) using a Finnigan MAT Kiel III carbonate preparation device at Utrecht University. Long-term analytical precision was estimated to be \pm 0.07 for $\delta^{18} \mathrm{O}$ and \pm 0.03 for $\delta^{13} \mathrm{C}$ by measuring eleven standards (international NBS-19 and in house NAXOS) with each set of 38 samples. The Neogloboquadrina samples were analyzed in an ISOCARB common bath carbonate preparation device linked on-line to VG SIRA24 mass spectrometer also at Utrecht University. Isotope Values were calibrated to the PeeDeeBelemnite (PDB) scale. Analytical precision was determined by replicate analyses and by comparison to the international (IAEA-CO1) and in-house carbonate standard (NAXOS). Replicate analyses showed standard deviations of \pm 0.06 and \pm 0.1 for $\delta^{13} \mathrm{C}$ and $\delta^{18} \mathrm{O}$, respectively.

Size-normalized weights of the planktic foraminiferal species G. ruber were measured to estimate the amount of carbonate dissolution. These measurements were done on the same relative narrow size fraction $(212-300 \mu \mathrm{m})$ used for stable isotope analysis. The shells were weighed using a microbalance (precision $0.1 \mu \mathrm{g}$ ) and the mean weight is taken to represent that population.

Total numbers of the deep-dwelling planktic foraminiferal species Globorotalia truncatulinoides and Globoratalia crassaformis were counted on splits of the 150-600 $\mu \mathrm{m}$ size fractions from the wet, sieved freeze-dried sediment. The counts are expressed as number per gram dry sediment. Certain intervals of the core are characterised by high abundances of "green grains", which were counted on the same sample splits and are expressed as number per gram dry sediment.

\section{Results}

\subsection{Chronology}

Age constraints are based on correlating the benthic $\delta^{18} \mathrm{O} U$. peregrina record to the LR04 benthic oxygen isotope stack (Lisiecki and Raymo, 2005) (Fig. 2). This correlation shows that MD04-2881 covers the past $\sim 750000$ years, although the oldest $\sim 100000$ years are less well confined. The amplitude variations in the $\delta^{18} \mathrm{O} U$. peregrina record are comparable to the global benthic stack, except for the interval below $\sim 600 \mathrm{ka}$, which shows only minor variations. The planktic $\delta^{18} \mathrm{O}$ records from $N$. dutertrei and $G$. ruber largely confirm the benthic isotope chronology. We do not find exceptionally light isotope values in any of the two planktic records during MIS 13, thereby questioning a monsoon related basin-wide flooding event in the northern Indian Ocean during MIS 13 (Rossignol-Strick et al., 1998). On the other hand, one could argue that also today most of the large river runoff from India is directed towards the Bay of Bengal and, therefore, the local salinity in the northern Arabian Sea was potentially less affected by an extreme increase in monsoon feed river discharge in the past. Similar to the U. peregrina record, a dampened $\delta^{18} \mathrm{O}$ signal is found in the record of $N$. dutertrei beyond $\sim 650 \mathrm{ka}$. The resulting age model indicates that interglacial periods are characterised by lower sedimentation rates compared to glacial periods. Sedimentation rate is, in particular, low during MIS 5 which may even suffer from a hiatus.

The reason for the dampened isotopic signal in the lower part of the core has not yet been solved, but it is well known 


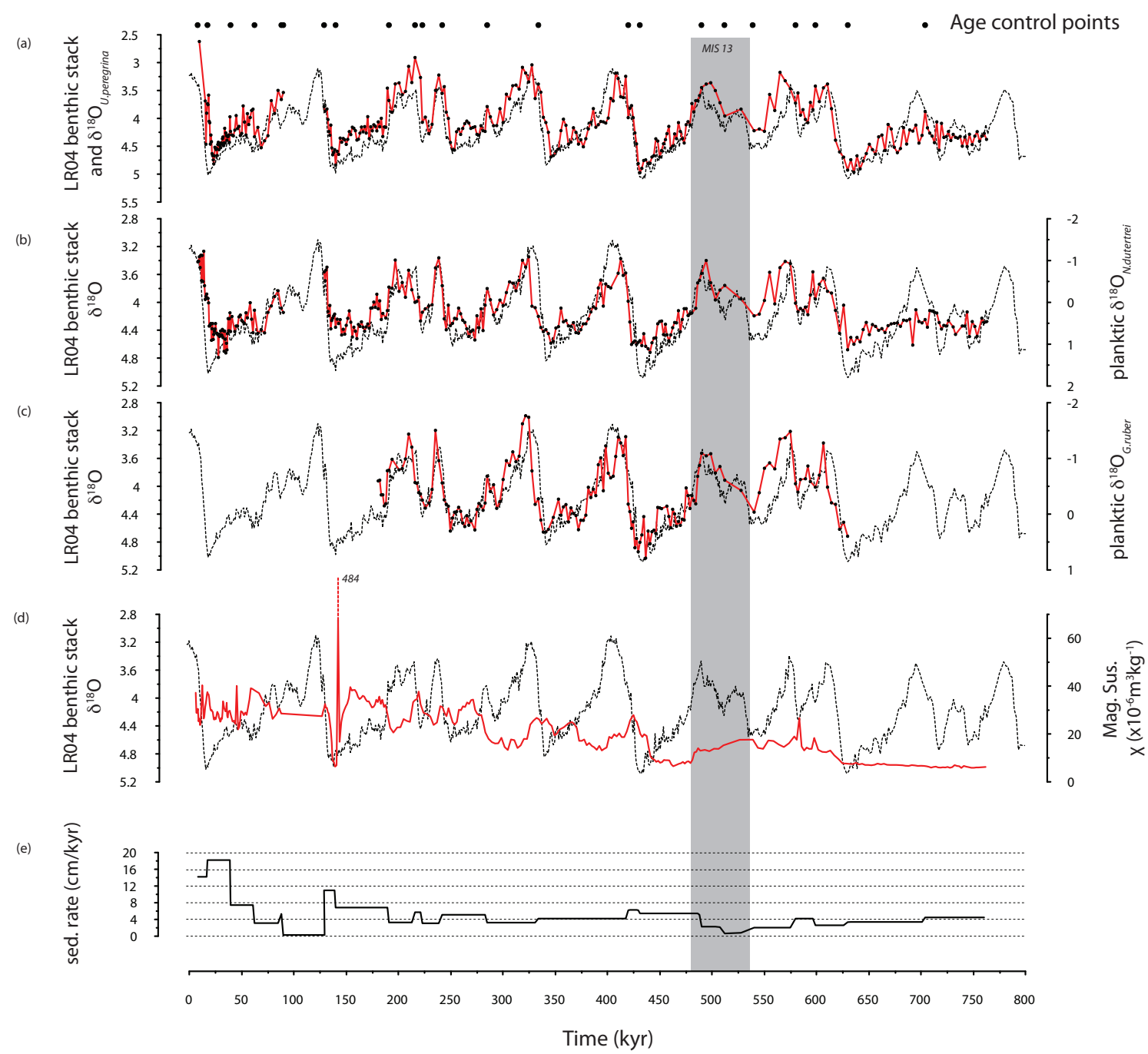

Fig. 2. Stable isotope records from MD04-2881 versus the global benthic isotope stack LR04 (black stippled line) (Lisiecki and Raymo, 2005). (a) Benthic $\delta^{18} \mathrm{O}$ (Uvigerina perigrina). (b) Planktic $\delta^{18} \mathrm{O}$ of Neoglobigerina dutertrei. (c) Planktic $\delta^{18} \mathrm{O}$ of Globigerinoides ruber. (d) Magnetic susceptibility. (e) Sedimentation rates of MD04-2881.

that the benthic isotope signal in the Arabian Sea has been altered by OMZ variability through changes in carbonate ion concentrations and supralysoclinal dissolution (Schmiedl and Mackensen, 2006). Furthermore, changes in Arabian Sea intermediate water masses between glacial and interglacial periods potentially influence the isotope signal (Jung et al., 2001; Zahn et al., 1991), although it is not clear why this would affect both benthic and planktic $\delta^{18} \mathrm{O}$ records. Perhaps an increased diagenetic alteration of the isotopic signal with depth may have played a critical role. Clearly, the magnetic susceptibility record of MD04-2881 shows a decreasing down-core trend with flat values below $\sim 650 \mathrm{ka}$ (Fig. 2), indicating the diagenetic removal of the magnetic properties in the sediment by the decomposition of organic matter and associated changes in the redox conditions of the pore waters within this interval (Reichart et al., 1997).

\subsection{OMZ intensity and productivity changes}

Marine organic carbon (MOC) content of Murray Ridge sediment cores has previously been used as productivity and/or OMZ intensity proxy (Reichart et al., 1998). It has recently been shown that the $\mathrm{Br}$ counts from XRF scanning enabled a fast and robust procedure to estimate the MOC content of the sediment (Ziegler et al., 2008). The Br record of MD04-2881 indicates that maximum MOC contents occur during glacial periods, whereas the lowest values coincide with glacial terminations (Fig. 3). These minimum values are accompanied by peak occurrences of $G$. crassaformis and G. truncatulinoides (Fig. 3). G. crassaformis and G. truncatulinoides are deep-dwelling planktic foraminiferal species that reached high abundances in the Arabian Sea during extreme cold events in the North Atlantic (Reichart et al., 1998; 


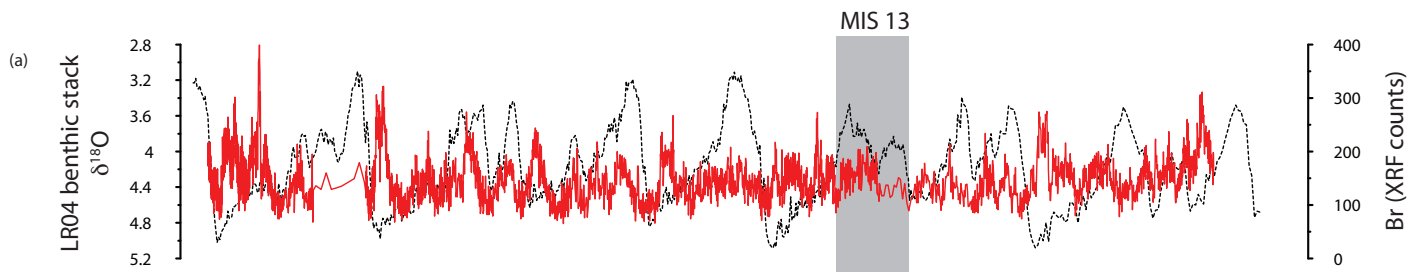

(b)

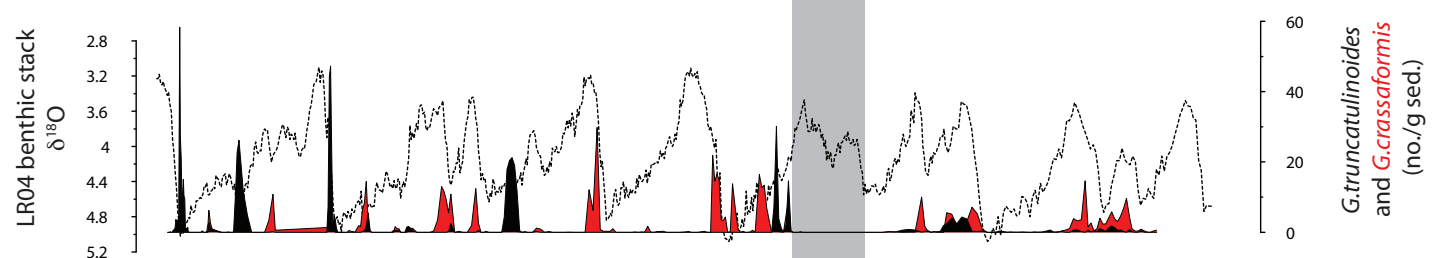

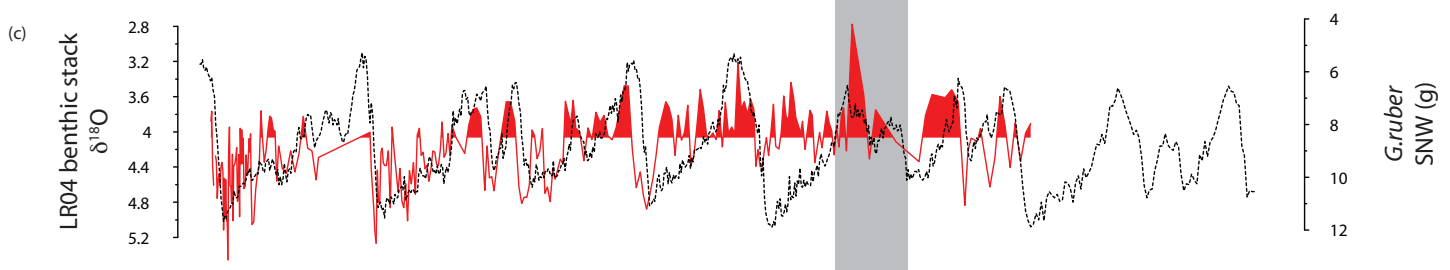

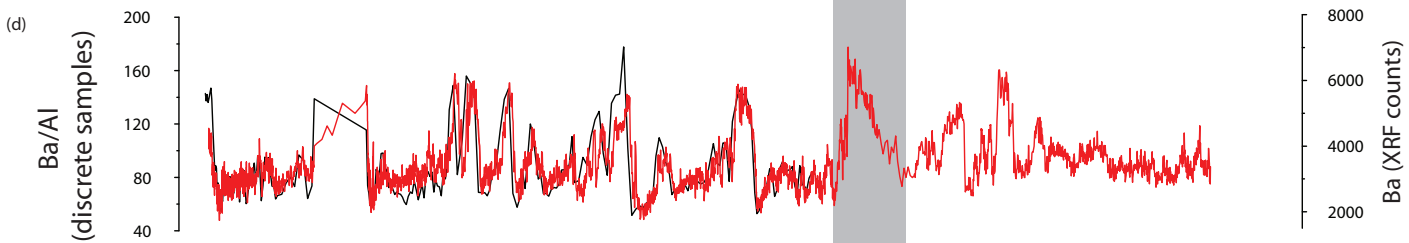

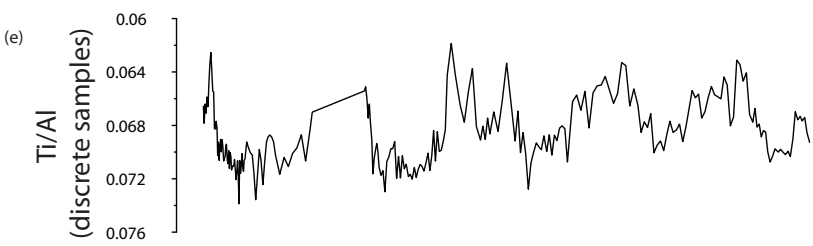

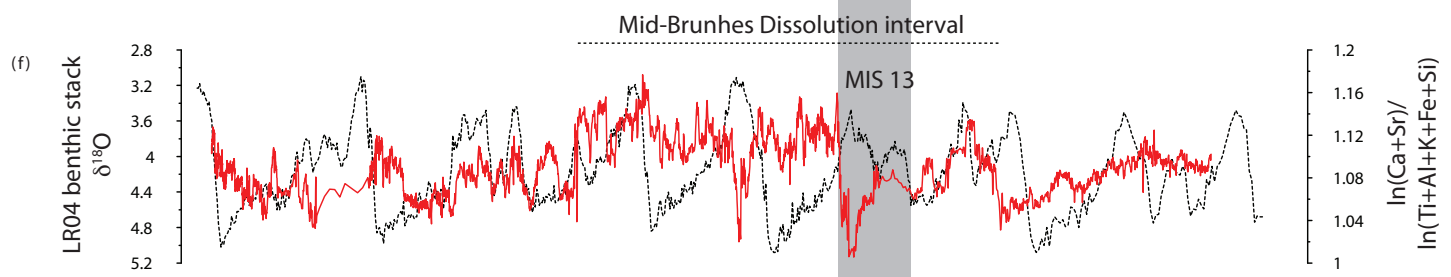

(g)

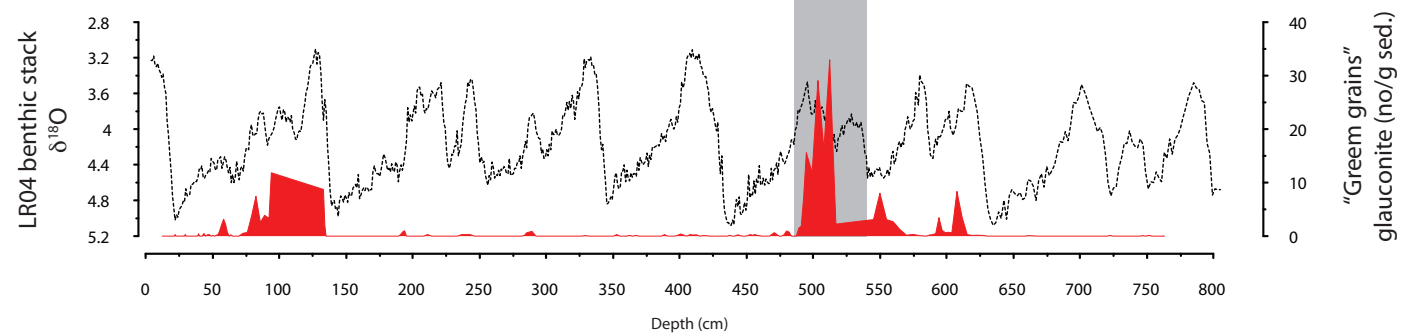

Fig. 3. Proxy records from MD04-2881 versus the global benthic isotope stack LR04 (black stippled line) (Lisiecki and Raymo, 2005). (a) Bromine counts (XRF-core scanning). (b) Occurrence of Globorotalia truncatulinoides and Globorotalia crassaformis. (c) Ba/Al (black line; XRF measurements on discrete samples) and Ba counts (red line; XRF-core scanning). (d) Size normalized weights of G. ruber. (e) Ti/Al (XRF measurements on discrete samples). (f) $\mathrm{Ca}+\mathrm{Sr}$ over terrestrial elements (XRF-core scanning). (g) Green Grains (no/g sediment). 
Ziegler, 2009). Similar to the ice rafted debris layers in the North Atlantic, peak occurrences of the Globorotalids usually do not last for more than a few thousand years and their abundances always return to very low baseline values before rising again. It has been suggested that their occurrences are indicative for periods of intensified winter mixing due to extreme cold winter monsoons, resulting in a breakdown of the OMZ (Reichart et al., 1998). Others argued that evidence for the required salinity and/or sea surface temperature changes in such a mechanism are missing and that the winter mixing theory is, therefore, hypothetical (Schulte et al., 1999). These authors linked a break-down of the OMZ instead to processes in the global oceanic circulation. The interval from 470 to $570 \mathrm{ka}$ is remarkable, as it is the longest interval in the record where no $G$. crassaformis or G. truncatulinoides specimen occur.

Amongst others, Reichart et al. $(1997,1998)$ showed that the MOC content of the Murray Ridge records co-varies with other upwelling productivity indicators (e.g. Globigerina bulloides abundances and $\mathrm{Ba} / \mathrm{Al}$ ). $\mathrm{Ba}$, for instance, has been successfully applied as proxy for primary productivity (Dehairs et al., 1980; Gingele et al., 1999; Jacot Des Combes et al., 1999; Shimmield and Mowbray, 1991). Barite crystals precipitate in microenvironments within decaying organic matter (Dehairs et al., 1980). One problem in the interpretation of $\mathrm{Ba}$ as productivity indicator lies in the distinction of biogenic and detrital $\mathrm{Ba}$. Normalization with $\mathrm{Al}$ is, therefore, commonly used to assess the detrital $\mathrm{Ba}$ component (e.g. Gingele et al., 1999). The relative contribution of detrital Ba appears to be small at the Murray Ridge (Schenau et al., 2001), so that the Ba records we obtained from MD042881 by XRF scanning and discrete sampling will primarily reflect changes in productivity. Note that we will primarily use the raw counts for Barium in our discussion, because they are highly correlated with the $\mathrm{Ba} / \mathrm{Al}$ ratios derived from the discrete samples of the last $462 \mathrm{ka}$ (Fig. 3).

Evidently, the Ba record co-varies with the benthic oxygen isotope record, indicating highest primary productivity conditions during interglacial periods as was previously found (Shimmield, 1992). This implies that the maximum MOC contents during glacial periods, at the depth of our studied core, are most likely related to other processes than increased productivity conditions only, as has been suggested for other Arabian Sea MOC records (Clemens and Prell, 2003; Murray and Prell, 1992; Schmiedl and Leuschner, 2005).

A comparison of sediment cores from different water depths at the Murray Ridge indicated that relatively shallow cores from within the modern OMZ contain the highest MOC contents during interglacial periods and that they vary inphase with other productivity proxies, while the deeper sites (i.e. well below the present-day OMZ) contain the highest MOC contents during glacial periods (Ziegler, 2009). This suggests that the oxygen content, of the bottom water at the core depth, and thereby the extension of the OMZ, is an important factor in controlling the depth dependent preservation of organic matter. Primary productivity is a second factor, which becomes dominant in records that are constantly within the OMZ. Higher sedimentation rates during glacial periods would have further facilitated the preservation of organic carbon (Clemens and Prell, 2003), but this process cannot explain the differences in MOC content between various water depths. On this basis, we may conclude that the $\mathrm{Br}$ enrichments during glacial periods in MD04-2881 coincide with an extreme downward extension of the OMZ. In turn, the relative low $\mathrm{Ba}$ concentrations within the MOC maxima during glacial periods could be due to early diagenetic processes. Arabian Sea sediments that are deposited well within the modern $\mathrm{OMZ}$ are characterised by high $\mathrm{C}_{\mathrm{org}} / \mathrm{Ba}_{\text {bio }}$ ratios, because of a lower preservation of Barite upon deposition through sulfate-reducing conditions (Schenau et al., 2001).

\subsection{Dissolution and dilution processes}

Bulk elemental concentrations of $\mathrm{Ca}$ and $\mathrm{Sr}$ versus the sum of $\mathrm{Al}, \mathrm{Si}, \mathrm{Ti}, \mathrm{Fe}$ and $\mathrm{K}$ reflect the input and preservation of biogenic carbonate versus the relative input of terrestrial material (Fig. 3). Because of its elevated location, the site is shielded from the input of turbidities and fan sedimentation of the Indus. The terrestrial material is, therefore, most likely eaolian (Reichart et al., 1997). Changes in the Ti/Al ratio of the sediments from the Murray Ridge have been applied in former studies as indicators for grain size and, thus, wind speed, since Titanium is concentrated in heavy minerals in the coarser size fraction (Reichart et al., 1997). The $\mathrm{Ti} / \mathrm{Al}$ record of MD04-2881 (derived from conventional XRF measurements on discrete samples, not from XRF scanning) shows a close relationship with glacial-interglacial variability (Fig. 3) as was previously found for the Oman Margin, with higher $\mathrm{Ti} / \mathrm{Al}$ values corresponding to an increased coarse-grained lithogenic flux into the Arabian Sea during dry glacial periods (Clemens et al., 1996). The total concentration of terrestrial elements in MD04-2881 shows, however, no clear glacial-interglacial variability. Several interglacial periods are even characterised by increased terrestrial element concentrations. This suggests that the bulk variations in terrestrial elements are dominated by the production and preservation of biogenic carbonate rather than by dilution.

Increased $\mathrm{Ca}$ and $\mathrm{Sr}$ contents and lower contents of terrestrial elements characterise the MBDI from 280 to $480 \mathrm{ka}$, with the exception of MIS 11 (Fig. 3). Similar to MD042881 , this carbonate plateau has been found in other Indian Ocean cores and was related to long-term eccentricity-driven cycles in the production of coccolithopores (Rickaby et al., 2007). Extreme minimum $\mathrm{Ca}$ and $\mathrm{Sr}$ contents coincide with MIS 5 and 13. These interglacial periods are characterised by the lowest sedimentation rates and, hence, point to periods of severe carbonate dissolution (Fig. 3). 
Calcite dissolution may occur above the lysocline when the metabolic release of $\mathrm{CO}_{2}$ during organic matter remineralization leads to carbonate under-saturation in the pore waters (Adler et al., 2001; Jahnke et al., 1994). This supralysocline dissolution process typically occurs below the OMZ in the Arabian Sea, where a high flux of organic material is accompanied by oxygen availability (Klöcker et al., 2007; Schulte and Bard, 2003; Tachikawa et al., 2008). The water depth of the studied core at around $2400 \mathrm{~m}$ was apparently strongly influenced by supralysoclinal dissolution during interglacial periods, when productivity conditions were significantly enhanced.

Size normalized weights (SNW) of planktic foraminifera have been used as an indicator for surface (Barker and Elderfield, 2002) and bottom water carbonate ion concentration $\left[\mathrm{CO}_{3}^{2-}\right]$ (Broecker and Clark, 2001; Lohmann, 1995). The SNW of G. ruber shows a good correlation with the $\mathrm{Ba}$ record, but also with the extensive $\mathrm{OMZ}$ intensities during the glacial periods (Fig. 3). This suggests that the SNW records may represent an even better picture of productivity variations in the Arabian Sea than the Ba record, which could have been altered during extended OMZ conditions. Anomalous low SNW values are found during MIS 13. Due to the complete dissolution of foraminifers during MIS 5, no SNW data could be obtained from this interval.

Furthermore, MIS 5 and 13 are characterised by large numbers of light green to dark green grains in the sand size fraction (Fig. 3). Green grains commonly occur at the edges of oxygen-minimum zones and are composed of authigenic minerals, most commonly Glauconite (Kelly and Webb, 1999; Mullins et al., 1985). They often form within granular substrates such as faecal pellets or foraminiferal chambers. Glauconite forms at or near the sediment surface and requires low sedimentation rates, so that enough time is available for biological alteration of detrital clay minerals (Worden and Morad, 2003). The process of glauconization is often associated with relatively shallow water depths $(<1000 \mathrm{~m})$. The core depth of $2347 \mathrm{~m}$ is, to our knowledge, one of the deepest water depth where in-situ Glauconite formation has been found yet (see also Wiewiora et al., 2001).

\section{Discussion}

\subsection{Intensity of the Indian-Asian monsoon}

The atmospheric methane record from Antarctic ice cores largely reflects the strength of tropical monsoon with a secondary input from boreal sources (Loulergue et al., 2008; Ruddiman and Raymo, 2003). Widespread wetlands, during periods of increased summer monsoon precipitation, are an important source of methane production when organic material decays under reducing conditions. Therefore, the atmospheric methane record provides important constraints for the interpretation of productivity changes and associated supralysoclinal dissolution intervals in our studied core from the Arabian Sea in terms of monsoon variability.

Currently, the longest methane record is derived from EPICA Dome C, which covers the last 800000 years (Fig. 4). Changes in methane concentrations are dominated by the 100-kyr glacial rhythm superimposed on the 23-kyr precession component (Loulergue et al., 2008; Spahni et al., 2005). The strong imprint of the precession cycle is consistent with the outcome of climate model experiments, which indicate that tropical monsoons respond primarily to changes in Northern Hemisphere summer insolation on orbital timescales (Kutzbach, 1981). The link between monsoon variations and methane concentrations is supported by East Asian summer monsoon records from Chinese speleothem records, which show the same precession phase for maximum summer monsoon intensity (Wang et al., 2008). Recently, we carried out a transient simulation with the intermediate complexity model CLIMBER-2 that included both insolation and ice volume variations (Weber and Tuenter, 2010; Ziegler, 2009). Indeed, this simulation reveals that the intensity of Indian-Asian summer monsoon precipitation responds to both forcing parameters, in accordance with the Antarctic methane record over the past $650 \mathrm{kyr}$ (Fig. 4). However, the methane record shows much stronger 100000 year glacial-interglacial component, which is probably introduced by methane contribution from boreal wetlands (Loulergue et al., 2008).

Overall, the variations in Ba and SNW records of MD042881 and, thus, productivity changes in the Arabian Sea and associated changes in the carbonate ion concentration of the water, share features with the methane record and model simulation (Fig. 4). However, a detailed comparison of the two records shows an almost anti-phase relationship at the precession scale. A further marked difference, is the anomalous high productivity peak and carbonate dissolution event associated with MIS 13. During this time, methane concentrations are lower than in every other interglacial period of the last 500000 years (Fig. 4). Also from a modelling perspective, the extreme summer monsoon maximum in MIS 13 is unexpected, because (1) benthic isotope records indicate that MIS 13 is a relatively cool interglacial (Lisiecki and Raymo, 2005), with remnant ice sheets in the Northern Hemisphere, and (2) Northern Hemisphere summer insolation maxima are not particularly strong in this period, although the earth's eccentricity was at a maximum around $500 \mathrm{ka}$ (Laskar et al., 1993).

We note that high productivity conditions in the Arabian Sea during MIS 13 linked to enhanced summer monsoon activity would to some extend match with earlier interpretations. The anomalous sapropel $(\mathrm{Sa})$ in the Mediterranean at $528-525 \mathrm{ka}$ and a synchronous peak in planktic oxygen isotope records from the equatorial Indian Ocean have been interpreted as indicators of an unusually heavy monsoon event over Africa and Asia at the start of MIS 13 (Bassinot et al., 1994a; Rossignol-Strick et al., 1998). However, 


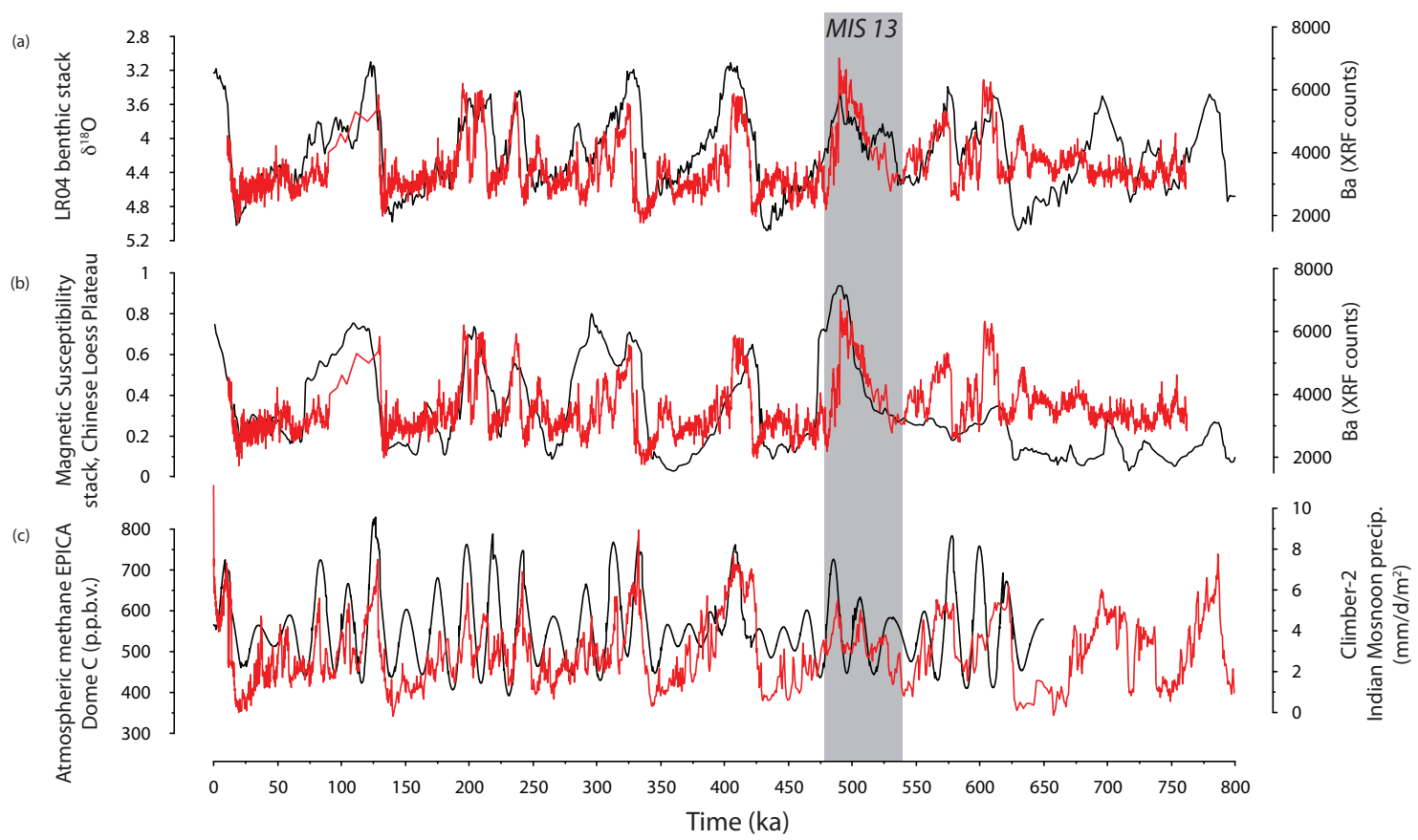

Fig. 4. Comparison between the Ba record of MD04-2881 and other paleoclimate-records. (a) Comparison with LR04 benthic isotope stack (b) Comparison with magnetic susceptibility stack from the Chinese Loess Plateau (Clemens et al., 2008). (c) Atmospheric methane concentration from EPICA Dome C (Loulergue et al., 2008) compared with modelled Indian monsoon precipitation (CLIMBER-2) (Ziegler, 2009; Weber and Tuenter, 2010).

more recently, the timing of the Sa sapropel was evaluated by Lourens (2004), showing that it occurs within MIS 14, $\sim 20000$ years earlier as originally proposed, thus, questioning the correlation with the isotope excursion in the equatorial Indian Ocean. In addition to that, the Eastern Mediterranean planktic oxygen isotope records presented by Lourens (2004) indicate no extreme freshwater signal in connection with the sapropel Sa.

In the following, we argue, based on the evidence from the methane record, that MIS 13 was most likely not characterised by an extreme, global summer monsoon event. This line of reasoning is further substantiated by new results from the Sanbao Cave speleothems. The extended cave record shows no anomalous isotope signature during MIS 13, arguing against abnormally high rates of precipitation during MIS 13 (H. Cheng, personal communication, 2009). We also note that the equatorial Indian Ocean isotope peak is a relatively short-lived event which contrasts the Arabian Sea productivity maximum, which appears to cover the whole MIS 13. This might indicate that different mechanisms are responsible for the observed events. As a consequence of our argumentation here, the equatorial Indian Ocean oxygen isotope excursion in MIS 13 requires a new explanation. Future research on new, long sedimentary records from the Bay of Bengal will provide additional information, which is necessary to solve this open question.

\subsection{Inferences from the Chinese loess plateau}

The Chinese loess plateau (CLP) is considered another important climate archive for the reconstruction of the Asian summer and winter monsoon as far back as 22 million years ago (Ding et al., 1995; Guo et al., 2002; Kukla et al., 1988; Porter and An, 1995). The winter monsoon transports dust from the Asian inlands to the CLP, while the summer monsoon brings precipitation (Porter and An, 1995). Successive loess and soil layers are, therefore, interpreted as alternating periods of strengthened winter (cold and dry) and summer monsoon (wet and warm), respectively. Recently it has been suggested that it is actually the breakdown of the Siberian High during spring that produces windstorms and associated dust deposition (Roe, 2009). Most proxies that have been used to unravel the history of the loess sequence (e.g. magnetic susceptibility) reflect the degree of chemical weathering and, thus, soil formation (Liu and Ding, 1998). Many loess records are dominated by glacial-interglacial variability superimposed by millennial scale events, which correlate to Heinrich events (Ding et al., 1995; Liu and Ding, 1998; Porter and An, 1995).

The $\mathrm{Ba}$ and, to a lesser degree, SNW records of MD042881 show a high similarity with a magnetic susceptibility stack from the CLP (Clemens et al., 2008). In contrast to the Antarctic methane record and model simulation, the exceptional high productivity conditions reached during MIS 13 coincided with an exceptional thick soil horizon S5 in 
some loess records of the central CLP (Guo et al., 2000; Sun et al., 2006b), and with an extreme event in a monsoon record from the Tibetan plateau (Chen et al., 1999). There are, however, noticeable regional differences in the expression of the S5 soil horizon (Sun et al., 2006a). While records from the central CLP expose a thick well-developed soil horizon, the S5 is hardly detected in the northwestern area. It was suggested that maximum intensities of summer monsoon precipitation did not reach this region until MIS 11 (Sun et al., 2006a). The latter observation is in much better agreement with the Antarctic methane record, which shows that methane concentrations were significantly lower during MIS 13 than during the interglacial periods after the MidBrunhes event, MBE, at $\sim 430 \mathrm{ka}$ (Loulergue et al., 2008; Spahni et al., 2005).

Another major difference between the loess records of the central and northwestern site of the CLP is that in the central region soil occurrences are determined by glacialinterglacial variability, while they exhibit a strong precession imprint in the northwest (Sun et al., 2006a). The latter observation is not only in good agreement with the Antarctic methane record, but also with the Indian-Asian summer monsoon reconstructions derived from the Chinese speleothem oxygen isotope records of the Sanbao and Hulu caves, which indicate primarily 23-kyr precession cycles over the last 225000 years (Wang et al., 2008). Similar to the loess records, the speleothem-derived monsoon record is overprinted by rapid events, which occur synchronously with climate variations in the North Atlantic region (Wang et al., 2005b; Wang et al., 2001).

\subsection{Cause of the extensive productivity conditions during MIS13}

Comparison of the Chinese loess records with temperature records from Antarctica have led to the suggestion that the climates of both hemispheres are unusually asymmetric during MIS 13 (Guo et al., 2009). Accordingly, Northern Hemisphere mean annual temperatures, evidenced by extreme soil formation in the Loess Plateau record, weakest Asian winter monsoon and lowest Asian dust and iron fluxes, were much warmer than at the Southern Hemisphere, because the global oxygen isotope record is characterised by relatively positive values (Guo et al., 2009). Moreover, the Deuterium $(\delta D)$ record of the EPICA Dome $\mathrm{C}$ ice core showed relatively cold interglacial temperatures during MIS 13, indicating that at least Antarctic temperatures were cold with respect to the successive interglacial periods (Jouzel et al., 2007). On the other hand, data from a glaciomarine sedimentary sequence from the West Antarctic continental margin suggest that the interval spanning MIS 15-13 was one single, prolonged interglacial period, which potentially experienced a collapse of the West Antarctic Ice sheet (Hillenbrand et al., 2009).

Warm Northern Hemisphere annual temperatures are consistent with the continuous forestation and inferred reduced mountain glaciations in central Eurasia throughout MIS 15 to 11 (Prokopenko et al., 2002). Tree growth is particularly sensitive to wintertime climate. Therefore, this period was probably characterised by mild winters, with relatively little snow cover. Such mild winter conditions would explain the absence of G. crassaformis or G. truncatulinoides in our Arabian Sea record in this interval. In addition, the higher winter temperatures may explain the thick soil horizon S5 in the central CLP. First it may facilitate pedogenesis through enhanced chemical weathering, and secondly a less intense winter monsoon may lead to a reduction of dust flux to the loess sites. As an alternative explanation from a modelling study, it was suggested that a precipitation maximum during MIS 13 could have occurred because of a reinforcement of the summer monsoon by an intermediate sized Eurasian ice-sheet (Yin et al., 2008). Such a scenario, however, does not explain the regional differences between the loess records and absence of a distinct monsoon event in the EPICA methane record during MIS 13. We, therefore, suggest that the anomalous climate patterns observed worldwide during MIS 13 are not primarily linked to changes in the intensity of the monsoon, but reflect an important turnover in the Atlantic circulation.

During the interim state of the MPT, the formation of North Atlantic deep water (NADW) was decreased and deep waters were influenced by a large Southern Hemisphere component (Raymo et al., 1997; Schmieder et al., 2000). Around $\mathrm{T}_{\mathrm{VI}}$, a series of events occurred in the South Atlantic, which point to a significant increase in NADW formation during that time (Gingele and Schmieder, 2001; Romero and Schmieder, 2006; Schmieder et al., 2000): (1) A very high production of NADW has been inferred from globally distributed benthic carbon isotope records (Raymo et al., 1997). (2) During MIS 13 an extreme $\delta^{13} C_{\max }$ occurs, which has been interpreted as a major reorganization in the carbon reservoir of the global ocean (Wang et al., 2001). (3) A certain group of benthic foraminifera became extinct (Gupta et al., 2006; Kawagata et al., 2006). (4) An increased poleward heat transport in the Atlantic Ocean has been evidenced by pollen records offshore Greenland (de Vernal and Hillaire-Marcel, 2008). These records suggest that the size of the Greenland ice-sheet was much more reduced than today, even though the benthic isotope record indicates a larger global ice volume during MIS 13.

A modelling study showed that increased NADW formation affects primary productivity and OMZ intensity in the Arabian Sea through increased nutrient availability on millennial time scales (Schmittner et al., 2007). In a separate study, we argued that the orbitally-induced primary productivity changes in the Arabian Sea are also very sensitive to the global ocean circulation rather than only summer monsoon intensity, therefore, causing a much longer precession phaselag (Ziegler, 2009). Similarly, we propose that the productivity peak and associated anomalous dissolution event during MIS 13 relates to increased Atlantic overturning circulation 
around $\mathrm{T}_{\mathrm{VI}}$. At the same time, increased heat transport to high northern latitudes might have caused the exceptionally mild winter conditions in Eurasia. Denton et al. (2005) suggested that the winter climate was much more sensitive to past changes in Atlantic meridional overturning, due to seaice related feedback mechanisms. Accordingly, intensified AMO may have resulted in mild winter conditions, facilitating soil formation on the central CLP. This implies that both Arabian Sea productivity and CLP soil formation was effectively decoupled from Asian summer monsoon intensity during MIS 13.

\section{Conclusions}

A high-resolution multi-proxy record from the north-eastern Arabian Sea of the past $750 \mathrm{ka}$ reveals productivity changes, which oscillate primarily in concert with the $\sim 100 \mathrm{kyr}$ glacial-interglacial rhythm. Highest productivity peaks are associated with interglacial periods. In contrast, the base of the OMZ deepens during glacial periods, suggesting that intermediate water ventilation played an important role. Termination $T_{V I}$ differs from the other major late Pleistocene terminations $\left(\mathrm{T}_{\mathrm{I}-\mathrm{V}}\right.$ and $\left.\mathrm{T}_{\mathrm{VII}}\right)$ by the absence of a strong winter monsoon-related event in the Arabian Sea. During MIS 13, primary productivity conditions were anomalously high and led to extreme carbonate dissolution and glauconitization in the deep-sea sediments. An intensive Atlantic overturning circulation during this time may have triggered mild winter conditions found in large parts of the Northern Hemisphere and, thereby, weakened the Asian winter monsoon. In turn, enhanced NADW production during $\mathrm{T}_{\mathrm{VI}}$ may have increased the supply of nutrients to the Arabian Sea, thereby, setting the stage for the anomalously high productivity conditions and the carbonate dissolution event during MIS 13. The presented interpretation constitutes an alternative view on MIS 13, which has been linked to an extreme boreal summer monsoon event in earlier studies. Future research, especially on long sedimentary records from the Bay of Bengal will potentially provide crucial information, which is necessary to finally answer the isotope stage 13 monsoon question.

Acknowledgements. This study is supported by the Research Council for Earth and Life Sciences (ALW) with financial aid from the Netherlands Organization for Scientific Research (NWO) to L. J. Lourens (grants 853.00.032 and 834.04.003). We thank Luc Beaufort for editorial comments, as well as Steven Clemens and an anonymous reviewer for their thoughtful comments, which helped to improve this manuscript. A. van Dijk, R. Giles, G. Ittmann, T. Richter and A. Vaars are thanked for the technical support. Jan-Willem Zachariasse, initiator of the CHAMAK-IODP cruise is particularly acknowledged as well as the other crew members of R/V Marion Dufresne and NIOZ technicians for their shipboard support.

Edited by: L. Beaufort

\section{References}

Adler, M., Hensen, C., Wenzhoefer, F., Pfeifer, K., and Schulz, H. D.: Modeling of calcite dissolution by oxic respiration in supralysoclinal deep-sea sediments, Mar. Geol., 177(1-2), 167189, 2001.

Almogi-Labin, A., Schmiedl, G., Hemleben, C., Siman-Tov, R., Segl, M., and Meischner, D.: The influence of the NE winter monsoon on productivity changes in the Gulf of Aden, NW Arabian Sea, during the last $530 \mathrm{ka}$ as recorded by foraminifera, Mar. Micropalontol., 40(3), 295-319, 2000.

Altabet, M. A., Higginson, M. J., and Murray, D. W.: The effect of millennial-scale changes in Arabian Sea denitrification on atmospheric CO2, Nature, 415(6868), 159-162, 2002.

Anderson, D. M., Overpeck, J. T., and Gupta, A. K.: Increase in the Asian Southwest Monsoon During the Past Four Centuries, Science, 297(5581), 596-599, 2002.

Barker, S., Archer, D., Booth, L., Elderfield, H., Henderiks, J., and Rickaby, R. E. M.: Globally increased pelagic carbonate production during the Mid-Brunhes dissolution interval and the $\mathrm{CO}_{2}$ paradox of MIS 11, Quaternary Sci. Rev., 25, 3278-3293, 2006.

Barker, S. and Elderfield, H.: Foraminiferal Calcification Response to Glacial-Interglacial Changes in Atmospheric $\mathrm{CO}_{2}$, Science, 297(5582), 833-836, 2002.

Bassinot, F. C., Labeyrie, L. D., Vincent, E., Quidelleur, X., Shackleton, N. J., and Lancelot, Y.: The astronomical theory of climate and the age of the Brunhes-Matuyama magnetic reversal, Earth Planet. Sci. Lett., 126(1-3), 91-108, 1994a.

Bassinot, F. C., Beaufort, L., Vincent, E., Labeyrie, L. D., Rostek, F., Müller, P. J., Quidelleur, X., and Lancelot, Y.: Coarse fraction fluctuations in pelagic carbonate sediments from the tropical Indian Ocean: a $1500 \mathrm{kyr}$ record of carbonate dissolution, Paleoceanography, 9(4), 579-609, 1994b.

Bollmann, J., Baumann, K. H., and Thierstein, H. R.: Global dominance of Gephyrocapsa coccoliths in the late Pleistocene:selective dissolution, evolution or global environmental change?, Paleoceanography, 13, 517-529, 1998.

Broecker, W. and Clark, E.: An evaluation of Lohmann's Foraminifera Weight Dissolution Index, Paleoceanography, 16(5), 531-534, 2001.

Budziak, D., Schneider, R. R., Rostek, F., Müller, P. J., Bard, E., and Wefer, G.: Late Quaternary insolation forcing on total organic carbon and C-37 alkenone variations in the Arabian Sea, Paleoceanography, 15(3), 307-321, 2000.

Chen, F. H., Bloemendal, J., Zhang, P. Z., and Liu, G. X.: An 800 ky proxy record of climate from lake sediments of the Zoige Basin, eastern Tibetan Plateau, Palaeogeogr. Palaeocl., 151, 307-320, 1999.

Clark, P. U., Archer, D., Pollard, D., Blum, J. D., Rial, J. A., Brovkin, V., Mix, A., Pisias, N. G., and Roy, M.: The middle Pleistocene transition: characteristics, mechanisms, and implications for long-term changes in atmopheric $p \mathrm{CO}_{2}$, Quaternary Sci. Rev., 25, 3150-3184, 2006.

Clemens, S. C., Prell, W. L., Murray, D. W., Shimmield, G., and Weedon, G.: Forcing mechanisms of the Indian Ocean monsoon, Nature, 353(6346), 720-725, 1991.

Clemens, S. C., Murray, D. W., and Prell, W. L.: Nonstationary Phase of the Plio-Pleistocene Asian Monsoon, Science, 274(5289), 943-948, 1996. 
Clemens, S. C. and Prell, W. L.: Late Pleistocene Variability of Arabian Sea Summer Monsoon Winds and Continental Aridity: Eolian Records from the Lithogenic Component of Deep-Sea Sediments, Paleoceanography, 5(2), 109-145, 1990.

Clemens, S. C. and Prell, W. L.: A 350000 year summer-monsoon multi-proxy stack from the Owen Ridge, Northern Arabian Sea. Mar. Geol., 201(1-3), 35-51, 2003.

Clemens, S., Prell, W. L., Sun, Y., Liu, Z., and Chen, G.: Southern Hemisphere forcing of Pliocene $\delta 180$ and the evolution of Indio-Asian monsoons, Paleoceanography, 23, PA4210, doi:10.1029/2008PA001638, 2008.

de Vernal, A. and Hillaire-Marcel, C.: Natural Variability of Greenland Climate, Vegetation, and Ice Volume During the Past Million Years, Science, 320(5883), 1622-1625, 2008.

Dehairs, F., Chesselet, R., and Jedwab, J.: Discrete suspended particles of Barite and the Barium cycle in the open ocean, Earth Planet. Sci. Lett., 49, 528-550, 1980.

Denton, G. H., Alley, R. B., Comer, G. C., and Broecker, W. S.: The role of seasonality in abrupt climate change, Quaternary Sci. Rev., 24(10-11), 1159-1182, 2005.

Ding, Z. L., Liu, T. S., Rutter, N. W., Yu, Z. W., Guo, Z. T., and Zhu, R. X.: Ice-volume forcing of East Asian winter monsoon variations in the past 800000 years, Quaternary Res., 44, 149$159,1995$.

Droxler, A. W., Ferro, E. C., Mucciarone, D. A., and Haddad, G. A.: The marine carbonate system during oxygen isotope stage 11 (423-362 ka): a case of basin-to-shelf and/or basin-to-basin carbonate fractionation?, EOS, Trans. Am. Geophys. Un., 78, p. 179, 1997.

Droxler, A. W., Haddad, G. A., Mucciarone, D. A., and Cullen, J. L.: Pliocene-Pleistocene variations in aragonite content and planktonic oxygen-isotope record in Bahamian periplatform ooze, Hole 633A. Proc. Oc. Drill. Prog., Sci. Res., 101, 221-244, 1988.

Emeis, K., Anderson, D. M., Doose, H., Kroon, D., and SchulzBull, D.: Sea-Surface Tempertures and the History of Monsoon Upwelling in the Northwest Arabian Sea during the Last 500000 Years, Quarternary Int., 43, 355-361, 1995.

Gingele, F. X. and Schmieder, F.: Anomalous South Atlantic lithologies confirm global scale of unusual mid-Pleistocene climate excursion, Earth Planet. Sci. Lett., 186, 93-101, 2001.

Guo, Z. T., Berger, A., Yin, Q. Z., and Qin, L.: Strong asymmetry of hemispheric climates during MIS-13 inferred from correlating China loess and Antarctica ice records, Clim. Past, 5, 21-31, 2009, http://www.clim-past.net/5/21/2009/.

Guo, Z. T., Biscaye, P., Wei, L. Y., Chen, X. H., and Peng, S. Z.: Summer monsoon variations over the last $1.2 \mathrm{Ma}$ from the weathering of loess-soil sequences in China, Geophys. Res. Lett., 27, 1751-1754, 2000.

Guo, Z. T., Ruddiman, W. F., Hao, Q. Z., Wu, H. B., Qiao, Y. S., Zhu, R. X., Peng, S. Z., Wei, J. J., Yuan, B. Y., and Liu, T. S.: Onset of Asian desertification by $22 \mathrm{Myr}$ ago inferred from loess deposits in China, Nature, 416, 159-163, 2002.

Gupta, A. K., Anderson, D. M., and Overpeck, J. T.: Abrupt changes in the Asian southwest monsoon during the Holocene and their links to the North Atlantic Ocean, Nature, 421(6921), 354-357, 2003.
Gupta, A. K., Sarkar, S., and Mukherjee, B.: Paleoceanographic changes during the past 1.9 Myr at DSDP Site 238, Central Indian Ocean Basin: Benthic foraminiferal proxies, Mar. Micropaleontol., 60(2), 157-166, 2006.

Harris, S. E., Mix, A., and King, T.: Biogenic and terrigenous sedimentation at Ceara Rise, western tropical Atlantic, supports Pliocene-Pleistocene deep-water linkage between hemsipheres, Proc. Oc. Drill. Prog., Sci. Res., 154, 331-345, 1997.

Hillenbrand, C.-D., Kuhn, G., and Friederichs, T.: Record of a MidPleistocene depositional anomaly in West Antarctic continental margin sediments: in indicator for ice-sheet collapse?, Quaternary Sci. Rev., 28, 1147-1159, 2009.

Hönisch, B., Hemming, N. G., Archer, D., Siddall, M., and McManus, J.: Atmospheric Carbon Dioxide Concentration Across the Mid-Pleistocene Transition, Science, 324, 1551-1554, 2009.

Ishikawa, S. and Motoyoshi, O.: Reconstruction of Indian monsoon variability over the past 230000 years: Planktic foraminiferal evidence from the NW Arabian Sea open-ocean upwelling area, Mar. Micropaleontol., 63, 143-154, 2007.

Ivanova, E. M., Schiebel, R., Deo Singh, A., Schmiedl, G., Niebler, H.-S., and Hemleben, C.: Primary production in the Arabian Sea during the last 135000 years, Palaeogeogr. Palaeoclim., 197, 61$82,2003$.

Jacot Des Combes, H., Caulet, J. P., and Tribovillard, N. P.: Pelagic productivity changes in the equatorial area of the northwest Indian Ocean during the last 400000 years, Mar. Geol., 158, 27-55, 1999.

Jaeschke, A., Ziegler, M., Hopmans, E. C., Reichart, G.-J., Lourens, L. J., Schouten, S., and Sinninghe Damste, J. S.: Molecular fossil evidence for anaerobic ammonium oxidation in the Arabian Sea over the last glacial cycle, Paleoceanography, 24, PA2202, doi:10.1029/2008PA001712, 2009.

Jahnke, R., Craven, D. B., and Gaillard, J.-F.: The influence of organic matter diagenesis on $\mathrm{CaCO}_{3}$ dissolution at the dee-sea floor, Geochim. Cosmochim. Ac., 58(13), 2799-2809, 1994.

Jouzel, J., Masson-Delmotte, V., Cattani, O., Dreyfus, G., Falourd, S., Hoffmann, G., Minster, B., Nouet, J., Barnola, J. M., Chappellaz, J., Fischer, H., Gallet, J. C., Johnsen, S., Leuenberger, M., Loulergue, L., Luethi, D., Oerter, H., Parrenin, F., Raisbeck, G., Raynaud, D., Schilt, A., Schwander, J., Selmo, E., Souchez, R., Spahni, R., Stauffer, B., Steffensen, J. P., Stenni, B., Stocker, T. F., Tison, J. L., Werner, M., and Wolff, E. W.: Orbital and Millennial Antarctic Climate Variability over the Past 800000 Years, Science, 317(5839), 793-796, 2007.

Jung, S. J. A., Ganssen, G. M., and Davies, G. R.: Multidecadal variations in the early Holocene outflow of Red Sea Water into the Arabian Sea, Paleoceanography, 16(6), 658-668, 2001.

Kawagata, S., Hayward, B. W., and Gupta, A. K.: Benthic foraminiferal extinctions linked to late Pliocene-Pleistocene deep-sea circulation changes in the northern Indian Ocean (ODP Sites 722 and 758), Mar. Micropaleontol., 58(3), 219-242, 2006.

Kelly, J. C. and Webb, J. A.: The genesis of glaucony in the OligoMiocene Torquay Group, southeastern Australia: petrographic and geochemical evidence, Sediment. Geol., 125(1-2), 99-114, 1999. 
Klöcker, R., Ivanochko, T. S., Brummer, G.-J., Jung, S. J. A., Ganssen, G., Kroon, D., Ganeshram, R. S., and Henrich, R.: Variation in production, input and preservation of metastable calcium carbonate off Somalia during the last 90000 years, Quaternary Sci. Rev., 26(19-21), 2674-2683, 2007.

Kukla, G., Heller, F., Ming, L. X., Chun, X. T., Sheng, L. T., and Sheng, A. Z.: Pleistocene climates in China dated by magnetic susceptibility, Geology, 16, 811-814, 1988.

Kutzbach, J. E.: Monsoon climate of the early Holocene: climate experiment with Earth's orbital parameters for 9000 years ago, Science, 214, 59-61, 1981.

Laskar, J., Joutel, F., and Boudin, F.: Orbital, precessional, and insolation quantities for the Earth from -20 MYR to +10 MYR, Astron. Astrophys., 270(1-2), 522-533, 1993.

Leuschner, D. C. and Sirocko, F.: The low-latitude monsoon climate during Dansgaard-Oeschger cycles and Heinrich events, Quarternary Sci. Rev., 19, 243-254, 2000.

Leuschner, D. C. and Sirocko, F.: Orbital insolation forcing of the Indian Monsoon - a motor for global climate changes?, Palaeogeogr. Palaeoclim., 197, 83-95, 2003.

Lourens, L. J.: Revised tuning of Ocean Drilling Program Site 964 and KC01B (Mediterranean) and implications for the $\delta^{18} \mathrm{O}$, tephra, calcareous nannofossil, and geomagnetic reversal chronologies of the past 1.1 Myr, Paleoceanography, 19, PA3010, doi:10.1029/2003PA000997, 2004.

Lisiecki, L. E. and Raymo, M. E.: A Pliocene-Pleistocene stack of 57 globally distributed benthic delta O-18 records, Paleoceanography, 19, PA1003, doi:10.1029/2004PA001071, 2005.

Liu, T. and Ding, Z.: Chinese loess and the paleomonsoon, Annu. Rev. Earth Planet. Sci., 26, 111-145, 1998.

Lohmann, G. P.: A Model for Variation in the Chemistry of Planktonic Foraminifera Due to Secondary Calcification and Selective Dissolution, Paleoceanography, 10(3), 445-457, 1995.

Loulergue, L., Schilt, A., Spahni, R., Masson-Delmotte, V., Blunier, T., Lemieux, B., Barnola, J.-M., Raynaud, D., Stocker, T. F., and Chappellaz, J.: Orbital and millennial-scale features of atmospheric $\mathrm{CH}_{4}$ over the past 800000 years, Nature, 453(7193), 383-386, 2008.

Lückge, A., Doose-Rolinski, H., Khan, A. A., Schulz, H., and von Rad, U.: Monsoonal variability in the northeastern Arabian Sea during the past 5000 years: geochemical evidence from laminated sediments, Palaeogeogr. Palaeoclim., 167(3-4), 273-286, 2001.

Mullins, H. T., Thompson, J. B., McDougall, K., and Vercoutere, T. L.: Oxygen-minimum zone edge effects: Evidence from the central California coastal upwelling system, Geology, 13, 491494, 1985

Murray, D. W. and Prell, W. L.: Late Pliocene and Pleistocene climatic oscillations and monsoon upwelling recorded in sediments from the Owen Ridge, northwest Arabian Sea, in: Upwelling Systems: Evolution Since the Early Miocene, edited by: Summerhayes, C. P., Prell, W. L., and Emeis, K., Geol. Soc. Spec. Publ., 64, 301-324, 1992.

Naidu, P. D.: Link between western Arabian Sea surface temperature and summer monsoon strength and high-latitude abrupt climate events, J. Geol. Soc. India, 68(3), 379-385, 2006.
Naidu, P. D. and Malmgren, B. A.: A high-resolution record of late Quaternary upwelling along the Oman Margin, Arabian Sea based on planktonic foraminifera, Paleoceanography, 11(1), 129-140, 1996.

Pattan, J. N., Masuzawa, T., Naidu, P. D., Parthiban, G., and Yamamoto, M.: Productivity fluctuations in the southeastern Arabian Sea during the last $140 \mathrm{ka}$, Palaeogeogr. Palaeoclim., 193, 575-590, 2003.

Petit, J. R., Jouzel, J., Raynaud, D., Barkov, N. I., Barnola, J.-M., Basile, I., Bender, M., Chappellaz, J., Davis, M., Delaygue, G., Delmotte, M., Kotlyakov, Legrand, M., Lipenkov, V. Y., Lorius, C., Pepin, L., Ritz, C., Saltzman, E., and Stievenard, M.: Climate and atmospheric history of the past 420000 years from the Vostok ice core, Antarctica, Nature, 399, 429-436, 1999.

Porter, S. C. and An, Z.: Correlation between climate events in the North Atlantic and China during the last glaciation, Nature, 375(6529), 305-308, 1995.

Pourmand, A., Marcantonio, F., and Schulz, H.: Variations in productivity and eolian fluxes in the northeastern Arabian Sea during the past $110 \mathrm{ka}$, Earth Planet. Sci. Lett., 221, 39-54, 2004.

Prabhu, C. N. and Shankar. R.: Palaeopruductivity of the eastern Arabian Sea during the past $200 \mathrm{ka}$ : A multi-proxy investigation, Deep-Sea Res. Pt. II, 52, 1994-2002, 2005.

Prell, W. L. and Campo, E. V.: Coherent response of Arabian Sea upwelling and pollen transport to late Quaternary monsoonal winds, Nature, 323(6088), 526-528, 1986.

Prell, W. L., Hutson, W. H., Williams, D. F., Be, A. W. H., Geitzenauer, K. and Molfino, B.: Surface circulation of the Indian Ocean during the last glacial maximum, approximately 18,000 yr BP, Quaternary Res., 14(3), 309-336, 1980.

Prell, W. L. and Kutzbach, J. E.: Sensitivity of the Indian monsoon to forcing parameters and implications for its evolution, Nature, 360(6405), 647-652, 1992.

Prokopenko, A. A., Williams, D. F., Kuzmin, M. I., Karabanov, E. B., Khursevich, G. K., and Peck, J. A.: Muted climate variations in continental Siberia during the mid-Pleistocene epoch, Nature, 418(6893), 65-68, 2002.

Raymo, M. E., Lisiecki, L. E., and Nisancioglu, K. H.: PlioPleistocene Ice Volume, Antarctic Climate, and the Global $\delta^{18} \mathrm{O}$ Record, Science, 313, 492-495, 2006.

Raymo, M. E., Oppo, D. W., and Curry, W.: The mid-Pleistocene climate transition: A deep sea carbon isotopic perspective, Paleoceanography, 12(4), 546-559, 1997.

Reichart, G.-J., Brinkhuis, H., Huiskamp, F., and Zachariasse, W. J.: Hyperstratification following glacial overturning events in the northern Arabian Sea, Paleoceanography, 19(2), PA2013, doi:10.1029/2003PA000900, 2004.

Reichart, G.-J., den Dulk, M., Visser, H. J., van der Weijden, C. H., and Zachariasse, W. J.: A $225 \mathrm{kyr}$ record of dust supply, paleoproductivity and the oxygen minimum zone from the Murray ridge (northern Arabian Sea), Palaeogeogr. Palaeoclim., 134(14), 149-169, 1997.

Reichart, G.-J., Lourens, L. J., and Zachariasse, W. J.: Temporal variability in the northern Arabian Sea Oxygen Minimum Zone (OMZ) during the last 225000 years, Paleoceanography, 13(6), 607-621, 1998. 
Reichart, G.-J., Schenau, S. J., de Lange, G. J., and Zachariasse, W. J.: Synchroneity of oxygen minimum zone intensity on the Oman and Pakistan Margins at sub-Milankovitch time scales, Mar. Geol., 192(4), 437-438, 2002.

Richter, T. O., van der Gaast, S., Koster, B., Vaars, A., Gieles, R., de Stigter, H. C., de Haas, H., and van Weering, T. C. E.: The Avaatech XRF Core Scanner: Technical description and applications to NE Atlantic sediments, in: New Techniques in Sediment Core Analysis, edited by: Rothwell, R. G., Geol. Soc. Spec. Publ., 267, 39-50, 2006.

Rickaby, R. E. M., Bard, E., Sonzogni, C., Rostek, F., Beaufort, L., Barker, S., Rees, G., and Schrag, D. P.: Coccolith chemistry reveals secular variations in the global ocean carbon cycle?, Earth Planet. Sci. Lett., 253, 83-95, 2007.

Roe, G.: On the interpretation of Chinese loess as a paleoclimate indicator, Quaternary Res., 71, 150-161, 2009.

Romero, O. and Schmieder, F.: Occurence of thick Ethmodiscus oozes associated with a terminal Mid-Pleistocene Transition event in the oligotrophic subtropical South Atlantic, Palaeogeogr. Palaeoclim., 235, 321-329, 2006.

Rossignol-Strick, M., Paterne, M., Bassinot, F. C., Emeis, K., and de Lange, G. J.: An unusual mid-Pleistocene monsoon period over Africa and Asia, Nature, 392, 269-272, 1998.

Rostek, F., Bard, E., Beaufort, L., Sonzogni, C., and Ganssen, G.: Surface temperature and productivity records for the past $240 \mathrm{kyr}$ in the Arabian Sea, Deep-Sea Res. Pt. II, 44, 1461-1480, 1997.

Rostek, F., Ruhlandt, G., Bassinot, F. C., Müller, P. J., Labeyrie, L. D., Lancelot, Y., and Bard, E.: Reconstructing sea surface temperature and salinity using $\delta^{18} \mathrm{O}$ and alkenone records, Nature, 364(6435), 319-321, 1993.

Ruddiman, W. F. and Raymo, M.: A methane-based time scale for Vostok ice, Quaternary Sci. Rev., 22, 141-155, 2003.

Saher, M. H., Jung, S. J. A., Elderfield, H., Greaves, M. J., and Kroon, D.: Sea surface temperatures of the western Arabian Sea during the last deglaciation, Paleoceanography, 22, PA2208, doi:10.1029/2006PA001292, 2007.

Sarkar, A., Ramesh, R., Bhattacharya, S. K., and Rajagopalan, G.: Oxygen Isotope Evidence for A Stronger Winter Monsoon Current During the Last Glaciation, Nature, 343(6258), 549-551, 1990.

Schenau, S. J., Prins, M. A., De Lange, G. J., and Monnin, C.: Barium accumulation in the Arabian Sea: Controls on barite preservation in marine sediments, Geochim. Cosmochim. Ac., 65(10), 1545-1556, 2001.

Schmieder, F., von Dobeneck, T., and Bleil, U.: The MidPleistocene climate transition as documented in the deep South Atlantic Ocean: initiation, interim state and terminal event, Earth Planet. Sci. Lett., 179(3-4), 539-549, 2000.

Schmiedl, G. and Leuschner, D. C.: Oxygenation changes in the deep western Arabian Sea during the last 190,000 years: Productivity versus deepwater circulation, Paleoceanography, 20(2), 1-14, 2005.

Schmittner, A., Galbraith, E. D., Hostetler, S. W., Pedersen, T. F., and Zhang, R.: Large fluctuations of dissolved oxygen in the Indian and Pacific oceans during Dansgaard-Oeschger oscillations caused by variations of North Atlantic Deep Water subduction, Paleoceanography, 22, PA3207, doi:10.1029/2006PA001384, 2007.
Schulte, S. and Bard, E.: Past changes in biologically mediated dissolution of calcite above the chemical lysocline recorded in Indian Ocean sediments, Quarternary Sci. Rev., 22, 1757-1770, 2003.

Schulte, S., Rostek, F., Bard, E., Rüllkotter, J., and Marchal, O.: Variations of oxygen-minimum and primary productivity recorded in sediments of the Arabian Sea, Earth Planet. Sci. Lett., 173(3), 205-221, 1999.

Schulz, H., von Rad, U., and Erlenkeuser, H.: Correlation between Arabian Sea and Greenland climate oscillations of the past 110000 years, Nature, 393(6680), 54-57, 1998.

Shackleton, N. J. and Opdyke, N. D.: Oxygen-isotope and paleomagnetic stratigraphy of Pacific core V28-239: Late Pliocene to latest Pleistocene, Geol. Soc. Am. Mem., 145, 449-464, 1976.

Shimmield, G. B.: Can sediment geochemistry record changes in coastal upwelling palaeoproductivity? Evidence from northwest Africa and the Arabian Sea, in: Upwelling Systems: Evolution Since the Early Miocene, edited by: Summerhayes, C. P., Prell, W. L., and Emeis, K., Geol. Soc. Spec. Publ., 64, 29-46, 1992.

Shimmield, G. B. and Mowbray, S. R.: The inorganic record of the Northwest Arabian Sea: A history of productivity variation over the last 400 k.y. from sites 722 and 724, Proc. Oc Drill., Sci. Res., 117, 409-429, 1991

Sirocko, F., Garbe-Schönberg, D., McIntyre, A., and Molfino, B.: Teleconnections between the Subtropical Monsoons and High-Latitude Climates During the Last Deglaciation, Science, 272(5261), 526-529, 1996.

Sirocko, F., Sarnthein, M., Erlenkeuser, H., Lange, H., Arnold, M., and Duplessy, J. C.: Century-scale events in monsoonal climate over the past 24000 years, Nature, 364(6435), 322-324, 1993.

Spahni, R., Chappellaz, J., Stocker, T. F., Loulergue, L., Hausammann, G., Kawamura, K., Flückiger, J., Schwander, J., Raynaud, D., Masson-Delmotte, V., and Jouzel, J.: Atmospheric Methane and Nitrous Oxide of the Late Pleistocene from Antarctic Ice Cores, Science, 310(5752), 1317-1321, 2005.

Sun, Y., Chen, J., Clemens, S. C., Liu, Q., Ji, J., and Tada, R.: East Asian monsoon variability over the last seven glacial cycles recorded by a loess sequence from the northwestern Chinese Loess Plaetau, Geochem. Geophy. Geosy., 7, Q12Q02, doi:10.1029/2006GC001287, 2006a.

Sun, Y., Clemens, S. C., An, Z., and Zhiwei, Y.: Astronomical timescale and palaeoclimatic implication of stcked 3.6-Myr monsoon records from the Chinese Loess Plateau, Quaternary Sci. Rev., 25, 33-48, 2006b.

Tachikawa, K., Sepulcre, S., Toyofuku, T., and Bard, E.: Assessing influence of diagenetic carbonate dissolution on planktonic foraminiferal $\mathrm{Mg} / \mathrm{Ca}$ in the southeastern Arabian Sea over the past $450 \mathrm{ka}$ : Comparison between Globigerinoides ruber and Globigerinoides sacculifer, Geochem. Geophy. Geosy., 9, Q04037, doi:10.1029/2007GC001904, 2008.

Tjallingii, R., Röhl, U., Kolling, M., and Bickert, T.: Influence of the water content on X-ray fluorescence core-scanning measurements in soft marine sediments, Geochem. Geophy. Geosy., 8, Q02004, doi:10.1029/2006GC001393, 2007.

Wang, P., Clemens, S. C., Beaufort, L., Braconnot, P., Ganssen, G., Jian, Z., Kershaw, P., and Sarnthein, M.: Evolution and variability of the Asian monsoon system: State of the art and outstanding issues, Quaternary Sci. Rev., 24(5-6), 595-629, 2005. 
Wang, P., Tian, J., Cheng, X., Liu, X., and Xu, J.: Carbon reservoir changes preceded major ice-sheet expansion at the mid-Brunhes event, Geology, 31(3), 239-242, 2003.

Wang, Y. J., Cheng, H., Edwards, R. L., He, Y., Kong, X., An, Z., Wu, J., Kelly, M. J., Dykoski, C. A., and Li, X.: The Holocene Asian Monsoon: Links to Solar Changes and North Atlantic Climate, Science, 308(5723), 854-857, 2005.

Wang, Y. J., Cheng, H., Edwards, R. L., Kong, X., Xiaohua, S., Chen, S., Wu, J., Jiang, X., Wang, X., and Zhisheng, A.: Millenial- and orbital-scale changes in the East Asian monsoon over the past 224000 years, Nature, 28, 1090-1093, 2008.

Wang, Y. J., Cheng, H., Edwards, R. L., An, Z. S., Wu, J. Y., Shen, C. C., and Dorale, J. A.: A high-resolution absolute-dated Late Pleistocene monsoon record from Hulu Cave, China, Science, 294(5550), 2345-2348, 2001.

Weber, S. L. and Tuenter, E.: The impact of varying ice sheets and greenhouse gases on the intensity and timing of boreal summer monsoons, Quaternary Sci. Rev., in review, 2010.

Wiewiora, A., Giresse, P., Petit, S., and Wilamowski, A.: A deep-water glauconitization process on the ivory coast-Ghana marginal ridge (ODP Site 959): Determination of $\mathrm{Fe} 3+-$ rich Montmorillonite in Green Grains, Clay. Clay Miner., 49, 540 558,2001
Worden, R. H. and Morad, S.: Clay minerals in sandstones: controls on formation, distribution and evolution. Clay-mineral cements in sandstones, Blackwell Publishing, Oxford, 3-41, 2003.

Qiuzhen Yin, Berger, A., Driesschaert, E., Goosse, H., Loutre, M. F., and Crucifix, M.: The Eurasian ice sheet reinforces the East Asian summer monsoon during the interglacial 500000 years ago, Clim. Past, 4, 79-90, 2008, http://www.clim-past.net/4/79/2008/.

Yin, Q. Z. and Guo, Z. T.: Strong summer monsoon during the cool MIS-13, Clim. Past, 4, 29-34, 2008, http://www.clim-past.net/4/29/2008/

Zahn, R. and Pedersen, T. F.: Late Pleistocene evolution of surface and mid-depth hydrography at the Oman Margin: planktonic and benthic isotope records at Site 724, Proc. Oc Drill., Sci. Res., 117, 291-308, 1991.

Ziegler, M.: Orbital forcing of the late Pleistocene boreal summer monsoon: Links to North Atlantic cold events and the El Niño Southern Oscillation, Geologica Ultraiectina, 313, 141 pp., 2009.

Ziegler, M., Jilbert, T., de Lange, G. J., Lourens, L. J., and Reichart, G.-J.: Bromine counts from XRF scanning as an estimate of the marine organic carbon content of sediment cores, Geochem. Geophy. Geosy., 9, Q05009, doi:10.1029/2007GC001932, 2008. 